\title{
Towards an Interreligious Ecotheological Leadership Paradigm to Overcome the Ecological Crisis
}

\author{
Aloys Budi Purnomo \\ Environment Science Doctoral Program in \\ Soegijapranata Catholic University of Semarang, Indonesia. \\ aloybudipurnomopr@gmail.com; aloys@unika.ac.id
}

\begin{abstract}
:
An increasingly complex ecological crisis due to misperceptions, wrong perspective and behaviour in managing the environment requires an interreligious ecotheological leadership paradigm to evaluate and change $i t$. However, there is no conceptualization of such leadership. This paper elaborates my personal praxis in involving to maintain the integrity of creation and the environment preservation to construct a paradigm of an interreligious ecotheological leadership in overcoming the ecological crisis. The praxis with the interreligious activists in three places namely Kendeng, Gedongsongo and Tambakrejo (Central Java) became a starting point of this reflection. Starting with an overview of environmental problems, an interreligious ecotheological praxis is performed. Then, I propose the interreligious ecotheological leadership as a new paradigm to evaluate misperception, wrong perspective and behaviour in order to overcoming ecological crisis. I also offer the six characteristics of an interreligious ecotheological leader based on my interreligious ecotheological praxis and some purposive literature. All is discussed and reflected in the lens of the interreligious ecotheology as a part of contextual theology based on the personal praxis supported by the available literature and the Catholic Social Teaching, especially the Laudato Si'.
\end{abstract}

\section{Keywords:}

Contextual theology, ecological crisis, eco-interreligious praxis, interreligious ecotheology, characteristics interreligius leader, interreligious ecotheological leader(ship) paradigm 


\section{INTRODUCTION: ETHICAL NOTE OF THIS PAPER AND SCHEMATIC STEPS OF THIS REFLECTION}

First of all, as an ethical publication, it should be noted that this article is a further development and discussion" of my paper titled "Constructing and Conducting an Interreligious Ecotheological in Environmental Science Perspective" which has been published by Blue Eyes Intelligence Engineering \& Sciences Publication in International Journal of Engineering and Advanced Technology (IJEAT) ${ }^{2}$. There are four fundamental differences between the two manuscripts. First, it is about the subject research. Previous writing was based on Tambakrejo case only, while in this article, there are three cases, namely North Kendeng Mountains Region case, Gedongsongo case and Tambakrejo case as well. Secondly, the first article focused on the analysis of the documentary film "Tambakrejo \#BergerakBersama" in combination with the involvement with the victims, while this paper uses the Tambakrejo case in relation to other cases as mentioned, without using or and analysing the documentary film as data for this article. The third is the perspective of reflection. The previous paper used the perspective of environmental science, while this paper uses a contextual theological perspective. Fourth, in term of the leadership characters as research finding, the first found only five characteristics of the interreligious ecotheological leadership, while this article finds six characteristics, with one fundamental addition, that is the character of faith, hope and love as a theological finding. With that ethical note, let's begin this journey of contextual theological reflection towards an interreligious ecotheological leadership paradigm to overcome the ecological crisis which afflicted the Earth, our common home.

An increasingly complex ecological crisis due to misperceptions, wrong perspective and behaviour in managing the environment requires an interreligious ecotheological leadership paradigm to evaluate and change it. Here I found a fundamental problem about the paradigm that should be addressed in dealing with the ecological crisis. Who might

1 This note is based on the "Author Guidelines" of this Journal of Asian Orientation in Theology (JAOT) stating that "Discussion notes related to articles previously published are welcome." Available at https: / / e-journal.usd.ac.id/index.php/JAOT/about/submissions, (accessed 31.12.2019).

2 Aloys Budi Purnomo, "Constructing and Conducting an Interreligious Ecotheological Leadership in Environmental Science Perspective," International Journal of Engineering and Advanced Technology (IJEAT) Volume-9, no. Issue-2. December 2019. Retrieval Number: B3544129219/2019CBEIESP DOI: 10.35940/ijeat.B3544.129219, (2019): 1497-1501. 
have the authority to do to reform of this paradigm? The answer is interreligious ecotheological leaders. But who are they? That's what will be answered through this reflective research. It is about the paradigm of interreligious ecotheological to overcome the ecological crisis.

In my view, the paradigm of the interreligious ecotheological leadership will be a relevant and significant in contextual theology to answer Pope Francis' call as well as a starting point for carrying out interreligious ecotheology. This reflection will be taken in five steps. First, I'll start by explaining three environmental issues that I've been involved in from a contextual theological standpoint. Then, in the second part, I provide a theological reflection on ecological praxis in the perspective of ecotheological solidarity. In the third part, I will elaborate the idea of the urgency of the interreligious ecotheological leadership by using the lens of ecotheology in interreligious perspective. In the fourth part, I propose the summary of recommendations by presenting the outcomes of this study based on the characteristics of the interreligious ecotheological leader(ship) in an effort to overcome the ecological crisis. Finally, this paper will be closed with an open conclusion for a further research process that will still be done.

In its ecological encyclical, Laudato Si': On Care for Our Common $H_{o m e}$, the highest leader of the Roman Catholic Church who uses the name of St. Francis (of Assisi) urged the need to establish a dialogue that should engage all people, whatever their religions and beliefs, to caring for the Earth as our common home. Pope Francis seemed to shout seriously about interreligious ecotheology when His Holiness wrote:

"I urgently appeal, then, for a new dialogue about how we are shaping the future of our planet. We need a conversation which includes everyone, since the environmental challenge we are undergoing, and its human roots, concern and affect us all. The worldwide ecological movement has already made considerable progress and led to the establishment of numerous organizations committed to raising awareness of these challenges. Regrettably, many efforts to seek concrete solutions to the environmental crisis have proved ineffective, not only because of powerful opposition but also because of a more general lack of interest. Obstructionist attitudes, even on the part of believers, can range from denial of the problem to indifference, nonchalant resignation or blind confidence in technical solutions. We require a new and universal solidarity.

3 Pope Francis, Laudato Si': On Care for Our Common Home (Vatican: Libreria Editrice Vaticana, 2015). Henceforth, the LS abbreviation is used for Laudato Si' in this paper. 
... All of us can cooperate as instruments of God for the care of creation, each according to his or her own culture, experience, involvements and talents."

Furthermore, in LS 200-201, Pope Francis reiterates that if a mistaken understanding of our own principles causes us to justify the destruction of nature, or the arbitrary actions of humans in the world of creation, as believers we must acknowledge that we have been unfaithful to treasure of wisdom that we must guard, protect and preserve. In fact, the majority of the inhabitants of this planet declare themselves to be believers. It should be that this encourages religions to enter into dialogue with a view to protecting nature, defending the poor, and building a network of fraternal mutual respect. An open and respectful dialogue is also needed among various ecological movements. The severity of the ecological crisis requires all of us to think about the common good and move forward on the path of dialogue that requires patience, self-discipline, and generosity.

This interreligious ecotheological message confirms the experience of many people who have been seriously and intensively involved in the practice of caring for the Earth, preserving the integrity of creation and the environment. At a minimum, after for at least eleven years undergoing that praxis (March 1, 2008 - March 1, 2019), I was also confirmed by this interreligious ecological statement and message. The message of the Argentinian Pope not only inspired the movement and interest in carrying out the interreligious ecological praxis, but also confirmed my idea about the interreligious ecotheological leadership that I was studying and developing in this essay. Through this paper, I will try to elaborate on the importance and urgency of the interreligious ecotheological leadership paradigm to overcome the ecological crisis. Departing from the reflections on the three environmental problems that I was struggling with, and confirmed by Pope Francis' message, I will examine the interreligious ecotheological leadership paradigm as an alternative to be developed in order to overcome the ecological crisis.

By the way, before exploring this investigation, let's look at the following chart. It can be referred to as the schematic steps of this interreligious ecotheological reflection. 


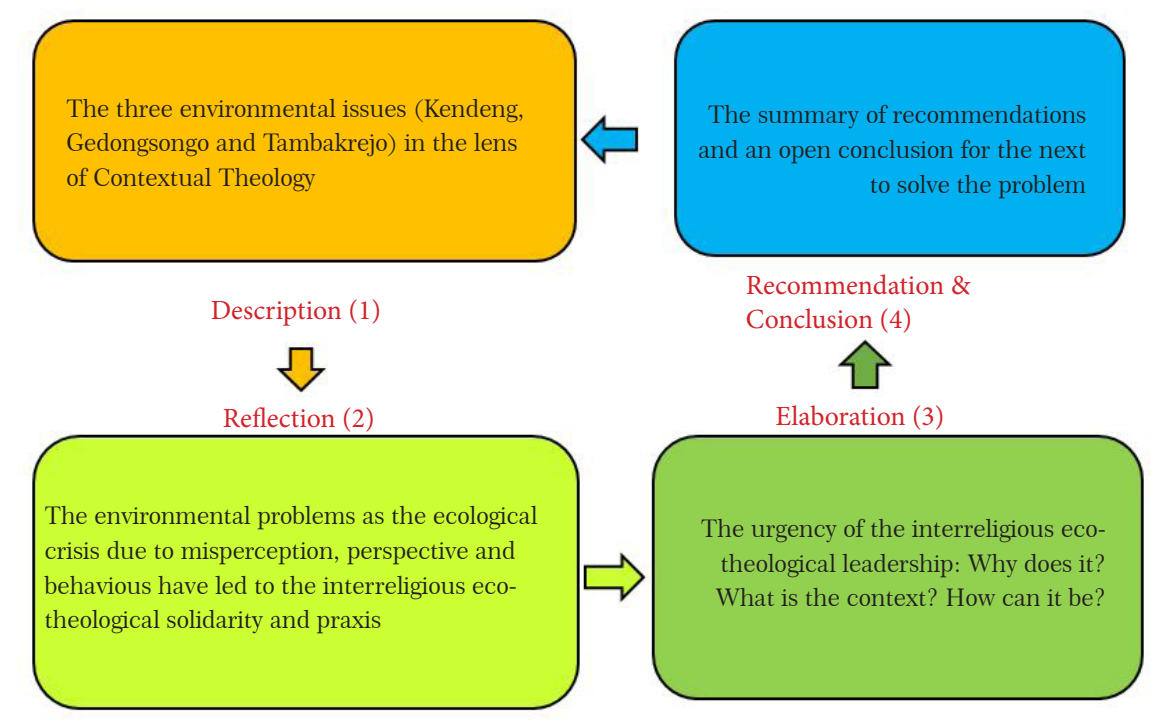

Figure 1: Schematic steps of reflection

There are environmental issues that are even part of the ecological crisis around us. This prompted the emergence of the interreligious ecotheology marked by solidarity and praxis with the victims and anyone who was moved to maintain the integrity of creation and environmental preservation. That is the context of the interreligious ecotheological leadership. The root of the matter is realized and attempted to be addressed by the interreligious ecotheological leaders. That is where recommendations about the characteristics of the interreligious ecotheological leaders can be described but still need to be developed continuously to look at the future, overcoming the ecological crisis for the next generation.

\section{Describing the Three Environmental Issues in the Lens of Contextual Theology}

The environmental problems that develop into an ecological crisis that afflicted the Earth as our common home ${ }^{5}$ have become a challenge to examine the existing leadership models and the paradigm of such as what is needed and can be offered to overcome this ecological crisis in the lens of contextual theology, especially in the lens of the interreligious

5 Pope Francis, Laudato Si', 2. See also Simon Western, "Eco-Leadership: Towards a New Paradigm” (2007), https://www.academia.edu/605304/Eco-Leadership_Towards_a_new_paradigm (accessed 12.09.2019). 
ecotheology. Two articles of Felix Wilfred ${ }^{6}$ and Julia Watts Belser ${ }^{7}$ have encouraged and motivated me to investigate the topic of constructing the interreligious ecotheological leadership paradigm to overcome the ecological crisis. They have confirmed both my experience of being involved in the interreligious ecological praxis and inspired me to develop an interreligious ecotheological leadership paradigm in overcoming crises. Their ideas helped me in reading my experience of being involved in the struggle against three real environmental problems before my eyes. What's the problem and how can we analyse it in the ecotheological lens as a contextual theology?

There are three environmental problems before our eyes, at least in my mind. Even though they are in different places, they have a common thread in terms of the problems associated with the environment namely abiotic/natural ecology, species/biotic ecology and economy as well as business ecology and the human environment or human ecolo$\mathrm{gy}^{8}$. Of course, the main common thread lies in the human aspect. In the language of Pope Francis ${ }^{9}$, the common thread of the problem is that the environmental problems have made the Earth scream because of all the damage that we have inflicted on it, because of our use and misuse which is not responsible for the wealth that God has placed in it. The Earth is burdened and destroyed, including the poor that we most ignore and harass. This idea is also in line with what KH Abdurrahman Wahid, the 4th President of the Republic of Indonesia, said that damaging nature is the same as damaging humanity. Damage to nature is damage to humanity. ${ }^{10}$

6 Felix Wilfred, "Toward Inter-Religious Eco-Theology," ed. Luiz Carlos Susin and Felix Wilfred Elaine Wainwright, Concilium 2009/3 (2009): 43-54, https://archive.org/details/ecotheology0000unse/page/n6. (access 09.09.2019)

7 Julia Watts Belser, "Environmental Justice and Interreligious Ecotheology," Religious Studies News, last modified 2013, http://rsn.aarweb.org/spotlight-on/theo-ed/environemental-justice/environmental-justice-and-interreligious-ecotheology (access 30.09.2019)

8 Lako, Andreas, et al), Pogram Doktor Ilmu Lingkungan, Arah Dan Filosofi Konsentrasi Kepemimpinan Lingkungan (Unika Soegijapranata Semarang, 2019).

9 Francis, Pope, "Laudato Si': Encyclical on the Environment," Origins, last modified 2015, https: / / focusoncampus.org/content/summary-of-laudato-si-pope-francis-encyclical-on-theenvironment-bfaf7861-99b2-413b-a736-9d883805ebc5., LS 2 (accessed 17.6.2019).

10 KH Abdurrahman Wahid and Daisaku Ikeda, "Dialog Peradaban Untuk Toleransi Dan Perdamaian” (Jakarta: PT Gramedia Pustaka Utama, 2013). See also Aloys Budi Purnomo, "Memperjuangkan Kemerdekaan Semesta,” Tribun Jateng (Semarang, 2019), https://jateng.tribunnews. com/2019/08/21/opini-aloys-budi-purnomo-memperjuangkan-kemerdekaan-semesta (ac- 
The first problem occurred in the North Kendeng Mountains Region ("Kawasan Pegunungan Kendeng Utara"/KPKU/Kendeng) especially in Pati, Rembang, Blora and Grobogan districts of Central Java, Indonesia, with victims of farmers. Problems arise related to the construction of cement plants which have an impact on the integrity of creation and environmental sustainability. The second problem is in Semarang Regency, with victims of residents who are threatened by the development plan of the Geothermal Power Plant (GPP). Problems that arise are related to the Gedongsongo Temple Cultural Heritage Area ("Kawasan Cagar Budaya Candi Gedongsongo"/KCBCG/Gedongsongo) which is also a Hindu traditional temple. The third problem occurred in the city of Semarang and is closely related to the humanity of Tambakrejo residents who were affected by the East Banjir Kanal River ("Sungai Banjir Kanal Timur"/ BKT/Tambakrejo) normalization project by the Mayor of Semarang City. The victims are the fishermen and their families.

These three problems in the perspective of environmental science can be put into two categories. Firstly, the first two problems at Kendeng and Gedongsongo are mining issues which not only have an impact on the environment but also local and surrounding residents. Specifically, the problem at Gedongsongo even includes two other issues namely related to cultural heritage and religious traditions, because besides being a cultural heritage area, Gedongsongo Temple is also a Hindu religious temple. Secondly, the third problem contains two problems, namely environmental problems in the form of floods, which would be resolved by normalizing the BKT river, but the process of river normalization had an impact on humanitarian issues because the Semarang City Government conducted eviction, which was considered inhumane and cause humanitarian concerns. 


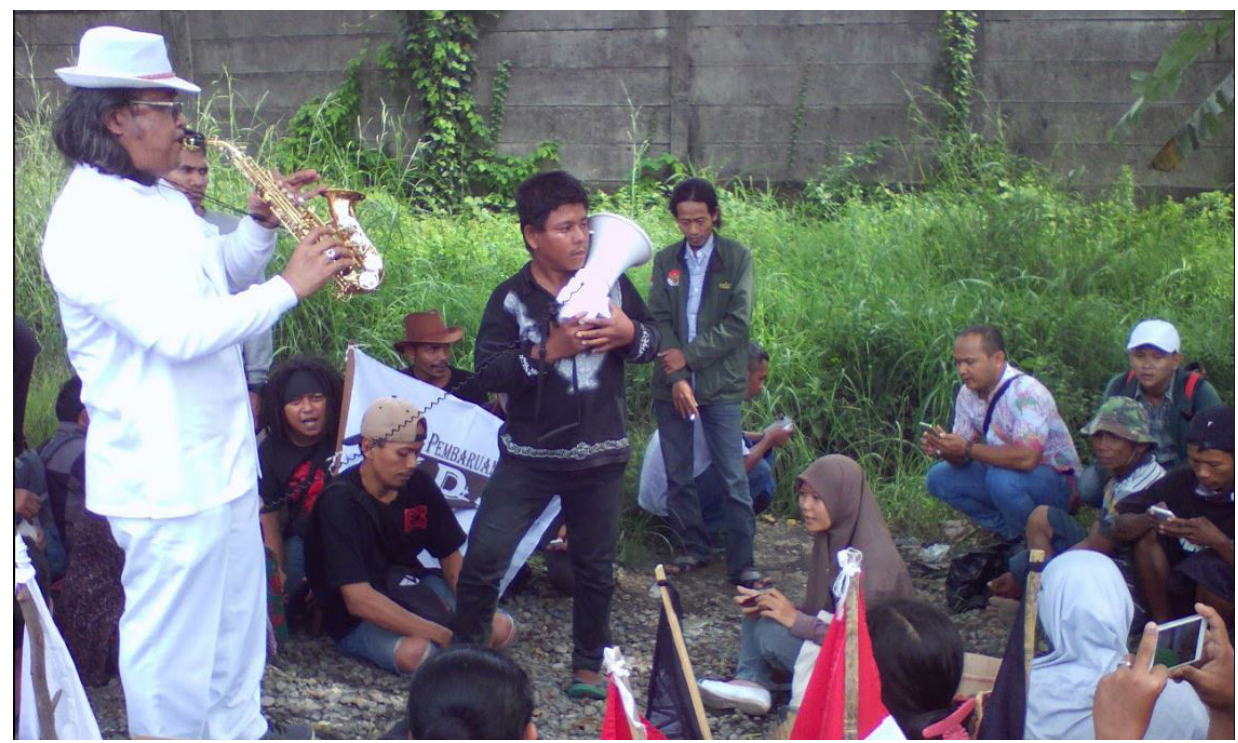

I'm strengthening Kendeng citizens demands ecological justice with my saxofon (Source: personal documentation)

Let's now focus on this brief description of each problem. First, in Kendeng, the environmental problems have been felt since 2006, when PT Semen Gresik would build a cement factory in Sukolilo District of Pati. Local residents of "Sedulur Sikep" (often called the "Samin Community") coordinated by Gunretno and Gunarti rejected the plan to build a cement factory because the construction was considered to threaten agriculture and springs in the area. In 2009, "Sedulur Sikep" Citizens won lawsuits from the State Administrative Court to the Supreme Court ("Pengadilan Tata Usaha Negara"/PTUN)11. PT Semen Gresik Indonesia also withdrew from Pati, but then moved to the District of Gunem, Rembang Regency under the name PT Semen Indonesia and set up a factory from June 17, 2014 to the present. In 2010 until 2019, the Indocement Group entered Pati with plans to build a cement factory in Kayen and Tambakromo Subdistricts, neighboring "Sedulur Sikep" village. Some Pati and Rembang residents (coordinated by Joko Prianto) together with "Sedulur Sikep" residents (Gunretno and Gunarti) faced PT. Semen Indonesia and the Indocement Group, in synergy with "Ja-

11 Aloys Budi Purnomo, "Reportase Long March Menjemput Keadilan Demi Keutuhan Ciptaan," Sesawi.Net, last modified 2015, http://www.sesawi.net/reportase-longmarch-menjemput-keadilan-demi-keutuhan-ciptaan/. See also L Gora Kunjana, "Menjaga-Bumi-Pertiwi-Warga-Kendeng-Longmarch-Ke-Semarang @ Www.Beritasatu.Com” (Jakarta: beritasatu.com, 2016), https://www.beritasatu.com/nasional/403670/menjaga-bumi-pertiwi-warga-kendeng-longmarch-ke-semarang (accessed 17.9.2019) 
ringan Masyarakat Peduli Pegunungan Kendeng" (JM-PPK, Network of Concerned Kendeng Mountain Community). Since 2010, in addition to Pati and Rembang, "JM-PPK" has also accompanied resistance to plans to construct cement plants in Grobogan (PT Vanda Firmalistri) and in Blora (PT Imasco Tambang Raya) ${ }^{12}$

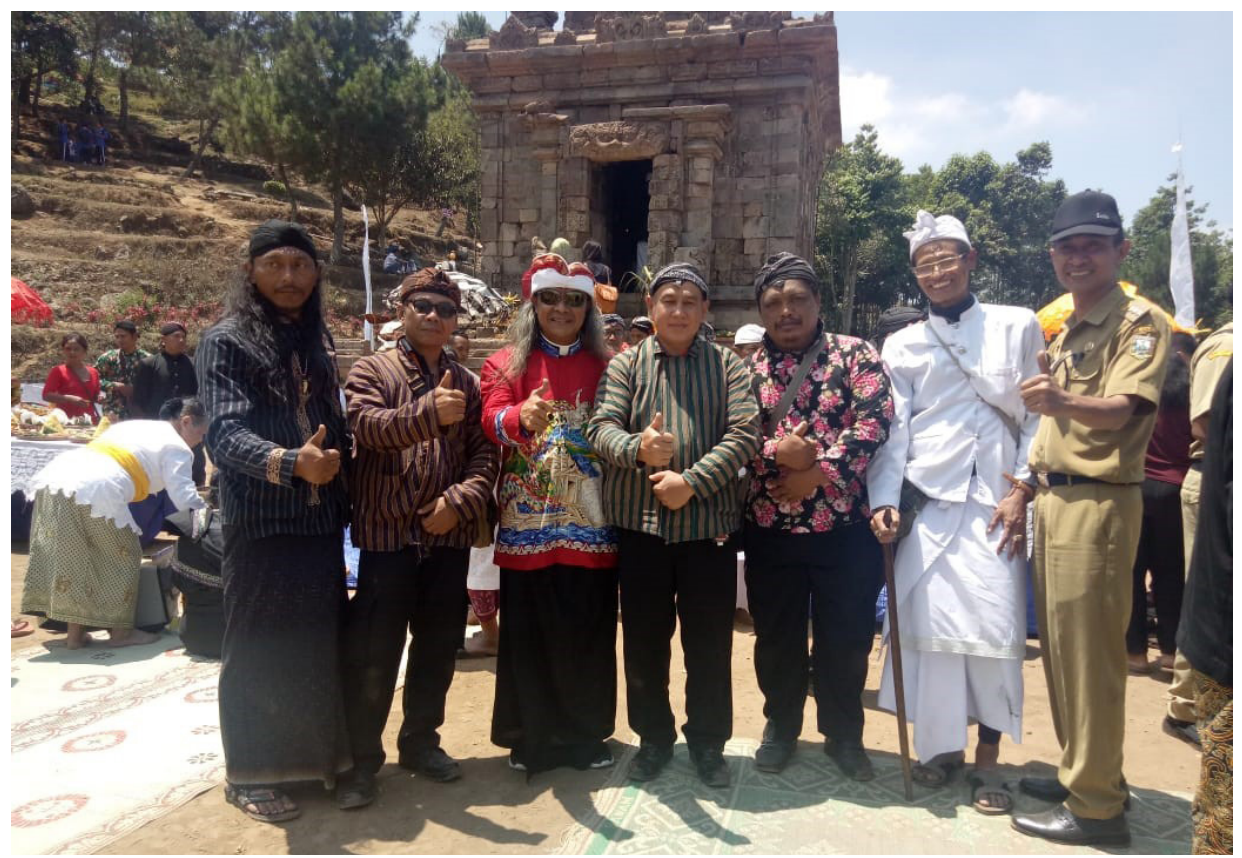

Together with interreligious leaders, we keep the temple of Gedongsongo

(Source: personal documentation)

Secondly, in Gedongsongo, environmental problems were triggered by plans to build a Geothermal Power Plant (GPP) on Mount Ungaran, near the Gedongsongo Temple cultural preservation. Since 2010, a number of residents who are members of the cultural arts community, environmentally caring communities and cultural conservation volunteers have refused. The reason, it is feared, the construction of GPP will damage the forest ecosystem and cultural preservation, damage nature and drain people's water reserves. Disturbances felt since the process of physical development began. Heavy equipment mobility disrupts traffic and residents' safety. In fact, the geothermal drilling process will also produce sili-

12 comANDRE, “Inspirasi Perlawanan Dari Warga Samin Lawan Industri Semen," Kaskus. Co.Id, last modified 2015, https://www.kaskus.co.id/thread/54f700db138b46fa278b4576/dokumenter-perjuangan-samin-melawan-industri-semen/ (accessed 17.09.2019). See also Finsensius Yuli Purnama, Semen vs Samin: The Impact of "Change. Ord" Online Petition in Perspective of Laudato Si', Reading Laudato Si' in Asia and the Pacific, vol. LII, Special Issue (Manila, 2017). 
ca and sulfur monoxide emissions, including arsenic and mercury, which will inevitably endanger residents. Not to mention the drilling process that can trigger local earthquakes and noise pollution. The government is asked to review the analysis of environmental impacts (EIA). GPP is built in an area which belongs to three areas in Bandungan Subdistrict, namely Candi, Kenteng and Kelungan Bandungan. GPP will also make other regions affected, namely Sumowono District, Semarang Regency; Boja District, Kendal Regency; and Gunungpati Sub-district, Semarang City. ${ }^{13}$ (Arh, 2019; Rachman, 2010).

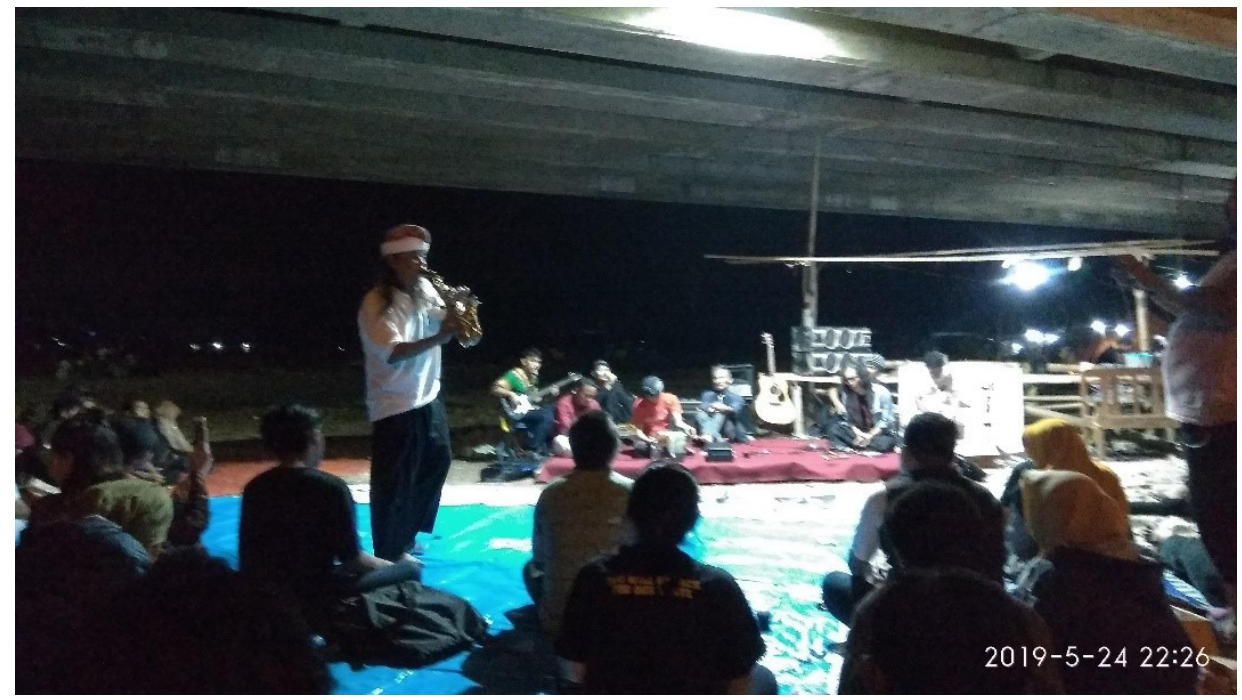

Strengthening Tambakrejo people in "Love Stage" after eviction (Source: https://justisia.com/2019/panggung-cinta-untuk-tambakrejo/, accessed 30.10.2019)

The third is a human ecology issue in Tambakrejo, Semarang City. The first main problem is the problem of flooding. City Government normalizes BKT river. Implementing the project is the Balai Pemali Juana River Region ("Balai Besar Wilayah Sungai Pemali Juana"/BBWS). The BKT normalization process had an impact on the relocation of Tambakrejo residents. Semarang City Government has provided a new place in the form of Rusunawa (Rumah susun sederhana sewa/ Simple Stacking House Rental) Kudu of Semarang City, but it is located in another

13 Arh, "Warga, Seniman, Dan Pegiat Lingkungan Hidup Menolak Pembangunan PLTPB Gunung Ungaran,” Tribun Jateng (Ungaran, 2019). See also Bowo Pribadi dan Taufik Rachman, "Warga Gedongsongo Tolak PLTTB,” Republika.Co.Id, last modified 2010, https://www.republika. co.id/berita/breaking-news/nusantara/10/08/09/128905-warga-gedongsongo-tolak-plttb (accessed 17.09.2019). 
place far from the sea. With the philosophy that like fish cannot be kept from the sea, so the small fishermen in Tambakrejo. Thus, they refused to be relocated to Rusunawa Kudu who was in the city, far from where they worked as a fisherman. As many as 97 families with at least 332 people, from children to the elderly of Tambakrejo residents also remained at the location. The problem became more complicated when the evictions took place which resulted in at least 97 families of Tambakrejo residents losing their houses, dwellings, which were leveled by the municipal government municipal police ("Satpol PP Pemkot"). There was resistance which was coordinated by Rochmadi, the head of the local residents and supported by activists, NGOs, LBH ("Lembaga Bantuan Hukum", Legal Aid), students, a number of artists and interreligious community leaders (including myself).

In the lens of contextual theology, especially in ecotheology perspective, all those problems are the problem of human ecotheology. Specifically, in the case of Kendeng and Tambakrejo, environmental problems that occur have also an eco-psycho-sociological impact on the humanity of citizens who are victims of development ${ }^{14}$. This eco-psycho-sociological impact is also eventually became a theological problem as Pope Francis is always concerned ${ }^{15}$. The same concern could be applied in Kendeng where the existence of a cement factory will make farmers lose their agricultural land and work as farmers along with damage to nature and springs, as well as damage to biodiversity ecosystems. The integrity of creation and the preservation of the environment are also threatened by future generations of humans which is a matter of Pope Francis concern as well ${ }^{16}$.

In Tambakrejo, the BKT normalization process has an impact on local residents namely Tambakrejo fishermen. As I mentioned before, like a fish cannot be separated from the water, so the fishermen cannot be far from the ocean. Eviction raises new problems related to human ecology, even a matter of environmental ecotheology. Those who suffer the most are children and women. The three problems are to connect, following

14 Kurt Lewin, Princuoles of Topological Psychology (New York and London: McGraw-Hill Book Company, Inc, 1936), 12.

15 Jeffrey Goh, "The Place of the Poor in Laudato Si'," Asian Horizons: Dharmaram Journal of Theology 9, no. 4 (2015): 645-657, http://w2.vatican.va/content/francesco/en/encyclicals/documents/papa-francesco_20150524_enciclica-laudato-si.html (accessed 17.07.2019).

16 Pope Francis, Laudato Si', 20 
Leonardo Boff reflection, the cry of the Earth with the cry of the oppressed. The most threatened of nature's creatures are the poor because human being and society always establish a relationship with the environment ${ }^{17}$.

\section{Environmental Problems, Ecological Crisis and Ecotheological Solidarity}

The three environmental problems that I mentioned are only a small part of the bigger problem, the increasingly tragic ecological crisis, namely the destruction of the universe and everything in it which includes abiotic elements (land, water, air, weather) and biotics (biodiversity of flora-fauna and human life) increasingly days are increasingly severe and complex ${ }^{18}$. Socio-psychologically, the crisis certainly had an impact on the psycho-sociological aspects of humanity, especially children ${ }^{19}$. The ecological crisis has an impact on the human aspect and requires in-depth study for equitable sustainable development. Precisely for this reason, strong leadership is needed, especially in cases that are complicated and fall into the "wicked problem" category ${ }^{20}$.

The three environmental issues discussed in this reflection can be placed in the context of an ecological crisis that threatens the Earth as our common home and human life. Ecological crisis is not only sufficiently discussed with many words, but must be supported by action. The action was called the praxis of interreligious ecotheological solidarity ${ }^{21}$ as I have done along with many activists who care to maintain the integ-

17 Leonardo Boff, Cry of the Earth, Cry of the Poor (New York: Orbis Books, 1997), 6.

18 A.M.C. Waterman, "Pope Francis on the Environmental Crisis," Independent Review, 2017, https://www.independent.org/publications/tir/article.asp?id=1182 (13.09.2019). See also Sean McDonagh, ed., On Care for Our Common Home. Laudato Si': The Encyclical Commentary (Maryknoll: Orbis Books, 2016); A. Sonny Keraf, Krisis Dan Bencana: Lingkungan Hidup Global (Yogyakarta: Kanisius, 2010).

19 Judith I. M. Steg, Linda, ed., Environmental Psychology : An Introduction, Second edi. (New Jersey: John Willey \& Sons, Inc, 2019), 12.

20 Y Budi Widianarko, Environmental Leadership (Semarang, 2019); Elin Kelsey \& Priya Fielding-Singh Nicole M. Ardoin, Rachelle K. Gould, "Collaborative and Transformational Leadership in the Environmental Realm," Journal of Environmental Policy \& Planning, 17:3, 360-380 (2015).

21 Peet J. van Dyk, “'Responsible Stewardship” - The Root of All Evil in Eco-Theology?,” OTE 28/2 (2015): 523-535 (2015), https://pdfs.semanticscholar.org/c344/90ecc21ae07a1b7c5c82fd2ca619c29e397a.pdf?_ga=2.142747699.726734814.1569827902-968639214.1569827902 (accessed 10.10.2019). 
rity of creation and the preservation of the environment.

With regard to the three environmental issues that are the focus of this paper, I not only see the problem from the outside as an observer, but also directly involved in the praxis of interreligious ecotheological solidarity. The praxis is a response to environmental problems that occur, in the joint movement of citizens as victims for the integrity of creation and environmental preservation. Praxis is made with the residents and interreligious community leaders.

Contextual theologically, I am involved in solidarity action through the practice of compassion for and with the citizens in the perspective of faith, hope and love $\mathrm{e}^{22}$ as a choice to prioritize and fight with the small, the weak, the poor, the excluded and disabled. That is what is called the option for and with the poor ${ }^{23}$ based on the liberative spirituality ${ }^{24}$. Together with residents and other activists, we are engaged in maintaining the integrity of creation and the preservation of the environment as a manifestation of faith, hope and love in praxis caring for the Earth ${ }^{25}$. Everything is in line with the Catholic Social Teachings on the social justice and ecological justice ${ }^{26}$.

The praxis also occurs together with friends and interreligious figures. For eleven years (March 1, 2008 - March 1, 2019) I served the Commission for Interreligious Affairs at the Archdiocese of Semarang. The joint involvement of citizens affected by the development process that includes social injustice and ecological injustice is one of the practices of building interreligious harmony and brotherhood.

The praxis with friends and interreligious community leaders in the context of "Kendeng Preservation" in Pati and Rembang or "Merti Bumi

22 Herry C Dalton, Anne M; Simmons, Ecotheology and the Practice of Hope (New York: Sunny Press, 2010).

23 Aloys Budi Purnomo, Preferential Option for and with the Poor (Medan: Bina Media, 2003). See also Leonardo Boff, Ecology and Liberation: A New Paradigm (New York: Orbis Books, 2000).

24 Aloys Budi Purnomo, Spiritualitas Pembebasan (Yogyakarta:Yayasan Pustaka Nusatama, 2002).

25 Aloys Budi Purnomo, "Praksis Merawat Bumi," Suara Merdeka (Semarang, August 2019), https://www.suaramerdeka.com/smcetak/baca/192145/praksis-merawat-bumi (accessed 02.09.2019).

26 Michael J Schuck, "Pope Francis Laudato Si', Concilium Vatican, last modified 2015, http:// w2.vatican.va/content/francesco/en/encyclicals/documents/papa-francesco_20150524_enciclica-laudato-si.html (accessed 17.06.2019). See also Donal Dorr, Option for the Poor and the Earth: Catholic Social Teaching (New York: Orbis Books, 2012). 
Serasi (Care for Earth Preservation)" in Gedongsongo or "Love Stage" in Tambakrejo is a form of "resistance" against "power" in order to defend humanity, namely the people affected by development and in the integrity of the creation and the preservation of the environment. Thus, in my opinion, the praxis should be called the praxis of the interreligious ecotheological solidarity. That praxis can be a starting point to find the urgency of interreligious ecotheological leadership in dealing with environmental and humanitarian problems. This is where the urgency of the appropriate leadership is needed in overcoming holistic environmental problems and ecological crises comprehensively. It is not only needed but it has to be most urgent as well!

\section{REFLECTIONS ON THE URGENCY OF THE INTERRELIGIOUS ECOTHEOLOGICAL LEADERSHIP}

Facing the existing environmental problems, it takes a leader figure who is able to provide solutions by prioritizing commitments to maintain the integrity of creation and environmental sustainability (abiotic-biotic ecology) and defend human dignity (human ecology) in the framework of sustainable development, based on the ecotheological concern. Therefore, in this section, I will reflect on two things. First, why do environmental problems continue to occur and the ecological crisis is increasingly severe and complex? Second, what kind of leadership is needed and how it is realized in the lens of ecotheology, especially the interreligious ecotheology?

\section{Mistakes of Perception, Perspectives, and Behaviour}

Environmental problems continue to occur due to the absent of the eco-philosophical mindset, lack of understanding of the ecotheological foundation, and misperceptions and behaviours of the leaders towards the universe and the environment. Eco-philosophically and ecotheologically, the ecological crisis continues to occur due to the errors of mindset, the wrong way of looking and the greed of human behaviour towards the universe and the environment. Misguided thinking, perspective and human behaviour even including socio-economic-political leaders that produce a variety of policies, practices and lifestyles that damage and destroy the environment are causing ecological crisis ${ }^{27}$.

27 A. Sony Keraf, Filsafat Lingkungan Hidup Alam Sebagai Sebuah Sistem Kehidupan (Yogyakarta: Kanisius, 2014), 8, 58, 67. See also Fritjof Capra, The Hidden Connections (London: Flamingo, 2003) and Fritjop. Capra and V. N. Mansfield, The Tao of Physics: An Exploration of the Parallels Between 
As a result of this misperception, Pope Francis ${ }^{28}$ reminds us, the universe and the environment are merely considered objects that can be exploited, dredged for a momentary economic gain. Future generations are ignored. Development does not produce justice, instead it gives birth to ecological injustice which even destroys humans. From a number of ecological surveys of various development projects that have taken place so far, the wrong perspective on the environment has made development projects leave new problems for the local community and environment. Unemployment increases. Certain natural reserves are depleting or even depleted. Deforestation, poor farming and local livestock are happening. Open natural holes. The hills are destroyed. Polluted river. A handful of investors' social work can no longer be continued.

Following Pope Francis consideration in the encyclical Laudato Si, the ecological crisis can be verified in some instances. First, a garbage wasting mentality leave a scene of poor, rotten aroma, spread of disease and water pollution of rivers and soils. Secondly, the use of fossil fuels (oil and gas) and coal has increased atmospheric pollution and resulted in traces of ecological damage to human life patterns. Thirdly, deforestation transforms the world's lung ecosystem into CO2 suction, damaging groundwater, eliminating biodiversity, and increasing land vulnerability to fires and floods. Fourth, the vehicle smoke resulted in air pollution, city temperature rise, social distress (stress), shortness of breath, and easily grow carcinogen cells (cancer cells) in the human body ${ }^{29}$.

\section{The Emergence of the Interreligious Ecotheology}

As we know it well in contextual theology ${ }^{30}$, the ecological crisis triggered the emergence of the ecotheology in the 1960s and 1970s, when Christian theologians increasingly realized the importance of developing a theology that was friendly and concerned about the environment. They sought to restore and reconstruct theological traditions and studies in various ways to overcome the ecological crisis, poverty, oppression and nuclear war. Ecotheology corrects doctrines and wrong attitudes, calls

Modern Physics Ad Eastern Mysticism, Physics Today, vol. 29 (Boston: Shambhala, Year: 2010, 1976).

28 Francis, Pope, Laudato Si',

29 Francis, Pope, Laudato Si', 17-61.

30 Andrew J. Spencer, "Beyond Christian Environmentalism: Ecotheology as an Over-Contextualized Theology," Themelios 40.3 (2015): 414-28 (2015). See also, Al. Purwa Hadiwardoyo, Teologi Ramah Lingkungan, Sekilas Tentang Ekoteologi Kristiani (Yogyakarta: Kanisius, 2015). 
for change of action, and contemplates all kinds of crises and environmental degradation ${ }^{31}$.

This effort is in accordance with the function of theology as an intermediary between religious traditions and socio-cultural contexts as suggested by Bernard Lonergan ${ }^{32}$. Ecotheology has a level of urgency and passion that shows the belief that caring for the environment is a matter of life and death for humanity, even for the planet ${ }^{33}$. Ecotheology does not only move in the realm of Christian faith, but also in synergy with interreligious figures. Therefore, the idea of interreligious ecotheology also emerged as suggested by Felix Wilfred ${ }^{34}$ and Julia Watts Belser ${ }^{35}$ in order to protect the Earth, our common home ${ }^{36}$.

According to Wilfred, the interreligious "eco-theology" is a common practice among religious believers in the framework of overcoming the ecological crisis. This practice is done for the safety of mankind in the context of political economic domination which is the cause of environmental problems and social injustice. The economic system of greed and competition as well as the uncontrolled production and consumption patterns will destroy the Earth even the extinction of mankind and the universe. In this perspective, the discourse of salvation which is a manifestation of faith is the concern of all religions. Greed, Earth instrumentalization, human manipulation and negation of justice occur through dominance and abuse of power. Thus, the Earth and its contents must be respected and should not be viewed as merely an object for the fulfilment of human greed ${ }^{37}$.

The same was realized by Julia Watts Belser of Missouri State University when making a reflective study titled Environmental Justice and Interreligious Ecotheology. With her students in the context of education,

31 Herry C Dalton, Anne M; Simmons, Ecotheology and the Practice of Hope (New York: Sunny Press, 2010), 27-8.

32 Bernard Lonergan, Method in Theology. (New York: Herder \& Herder, 1972).

33 Cobb John B, Is It Too Late? A Theology of Ecology (Denton, Texas: Environmental Ethics Books, 1995). See also Dalton, Anne M; Simmons, Ecotheology and the Practice of Hope, 35.

34 Wilfred, "Toward Inter-Religious Eco-Theology."

35 Belser, "Environmental Justice and Interreligious Ecotheology."

36 Pope Francis, Laudato Si', 201-202.

37 Wilfred, "Toward Inter-Religious Eco-Theology.", 44-45. See also Thomas Berry, The Christian Future and the Fate of Earth, ed. John Evelyn, Mary; Grim (Maryknoll, New York: Orbis Books, 2009), 1,4-5. 
Belser insists that theologians and scholars of religious studies often lack explicit attention to the issues of justice, violence and environmental destruction. She also realized the importance of the interreligious thinking about environmental theology, including examining the theological insight of scholars from other non-Christian traditions of religions.

Amid the idea of the importance of interreligious ecotheology, the call of Pope Francis in Laudato Si became significant and relevant in the expulsion of the interreligious ecotheological urgency. Let's once again look at the call of Pope Francis as I have alluded to in this section of the essay. Now let me cite it more fully and clearly to affirm the hope of the Holy Father.

“... Believers themselves must constantly feel challenged to live in a way consonant with their faith and not to contradict it by their actions. They need to be encouraged to be ever open to God's grace and to draw constantly from their deepest convictions about love, justice and peace. If a mistaken understanding of our own principles has at times led us to justify mistreating nature, to exercise tyranny over creation, to engage in war, injustice and acts of violence, we believers should acknowledge that by so doing we were not faithful to the treasures of wisdom which we have been called to protect and preserve. Cultural limitations in different eras often affected the perception of these ethical and spiritual treasures, yet by constantly returning to their sources, religions will be better equipped to respond to today's needs. ... The majority of people living on our planet profess to be believers. This should spur religions to dialogue among themselves for the sake of protecting nature, defending the poor, and building networks of respect and fraternity...." 38

\section{The Urgency of Interreligious Ecotheological Leadership Paradigm}

In this context, the urgency of interreligious ecotheological leadership paradigm has room, especially to evaluate and change the misguided mindset, outlook and behaviour that causes an ecological crisis. Interreligious ecotheological leaders are needed to build awareness and ways of thinking ecotheologically in humans together, without discrimination. The urgency of the interreligious ecotheological leadership to overcome environmental problems and the ecological crisis is even greater when the ecological crisis is increasingly endless even as an unending crisis.

38 Pope Francis, Laudato Si', 200-201. 
Thanks God that there are many models of leadership developed to overcome the ecological crisis. Yet, the various existing leadership concepts related to the environmental leadership have not provided a comprehensive solution in dealing with the ecological crisis and realize sustainable development that prioritizes the integrity of creation and environmental sustainability. During this time, environmental leadership tends to focus on specific companies or organizations ${ }^{39}$. The existing leadership concepts that refer to spiritual leadership ${ }^{40}$, environmental ${ }^{41}$, or transformational ${ }^{42}$, are certainly good in a corporate context. In the ecotheology, an idea was started about the eco-leadership ${ }^{43}$ as well as an ecological leadership ${ }^{44}$ and even interreligious ecotheology ${ }^{45}$ which certainly supports the presence of interreligious ecotheological leaders. The interreligious ecotheological leadership will be more effective when

Louis W. Fry, Spiritual Leadership - Global Encyclopedia of Public Administration, Public Policy, and Governance, ed. Ali (Ed) Farazmand, Springer International Publishing Switzerland (Florida Atlantic University Boca Raton, FL, USA: Global Encyclopedia of Public Administration, Public Policy, and Governance, 2018), https://www.iispiritualleadership.com/wp-content/uploads/ Spiritual-Leadership-Public-Administration_Final.pdf., 1-6, (accessed 17.06.2019). In reviewing this leadership model, I was also greatly assisted by the following articles: Jennifer L. and Robertson and and Erica Carleton, "Uncovering How and When Environmental Leadership Affects Employees' Voluntary Pro-Environmental Behavior,” Journal of Leadership \& Organizational Studies 1-14 14 (2017), https://doi.org/10.1177/1548051817738940\%0AArticle information \%0A. (accessed 10.09.2019); Chin Yi Chen and Chin Fang Yang, "The Impact of Spiritual Leadership on Organizational Citizenship Behavior: A Multi-Sample Analysis," Journal of Business Ethics 105, no. 1 (2012): 107-114; and Joanna Crossman, "Conceptualising Spiritual Leadership in Secular Organizational Contexts and Its Relation to Transformational, Servant and Environmental Leadership," Leadership and Organization Development Journal 31, no. 7 (2010): 596-608, www.emeraldinsight.com/0143-7739.htm (accessed 12.09.2019).

40 Crossman, "Conceptualising Spiritual Leadership in Secular Organizational Contexts and Its Relation to Transformational, Servant and Environmental Leadership.”

${ }^{41}$ Peter Case et al., "Rethinking Environmental Leadership: The Social Construction of Leaders and Leadership in Discourses of Ecological Crisis, Development, and Conservation," Leadership 11, no. 4 (2015): 396-423.

42 Nicole M. Ardoin, Rachelle K. Gould, "Collaborative and Transformational Leadership in the Environmental Realm.”

43 Western, "Eco-Leadership: Towards a New Paradigm."

44 Eric Brymer, "Ecological Leadership: A New Perspective on Leadership," Journal of Spirituality, Leadership and Management (SLaM), Spirituality, Leadership and Management Incorporated (NSW), St Josephs Centre for Reflective Living, Baulkham Hills, NSW, (2010): 84-94.

45 Belser, "Environmental Justice and Interreligious Ecotheology." and Wilfred, "Toward Inter-Religious Ecotheology." 
able to pay attention to aspects of environmental psychology as well as conceptualized by Hamman ${ }^{46}$ and Gifford ${ }^{47}$.

All ideas and models of environmental leadership are good and beneficial in a corporate context. But for the benefit of the wider community, we need a new paradigm of leadership that cares for the environment integrally and holistically. As I said before, precisely because this ecological crisis is largely due to the wrong mindset, misrepresentation and greedy behaviour, especially on the sides of socio-economic and political leaders, then, we need the presence of Interreligious leaders who care about ecology. Hopefully, they can evaluate and change the wrong behaviour and wrong mindset in caring for the Earth as our common home. This is where the space for the paradigm of interreligious ecotheological leadership to overcome this unending ecological crisis is gaining the right place and the right time. At the very least, my personal experience in the practice of maintaining the integrity of the creation and environmental sustainability has been proven to have a positive impact in addressing the environmental issues that occur. In this case I am not alone but moving with other religious leaders, activists and the civil society who care for the environment as a manifestation of our faith, whatever our religion and belief. Sustained by the teachings of every religion, in particular of Catholic Social Teaching and at least from the call of Pope Francis in Laudato Si', the hope of presenting the interreligious ecotheological leaders in overcoming the ecological crisis is increasingly relevant and significant. Here, I see the urgency of the interreligious ecotheological leadership for us all.

\section{SumMaRY OF RECOMMENDATIONS: the Nature And Out-Comes of The INTERReligious Ecotheological Leaders Characteristics}

How is the urgency of the interreligious ecotheological leadership applied in the context of the three environmental problems that are discussed in this paper? I have written this basic idea in popular language and published it as an opinion in Kompas Daily Newspaper with the

46 Daniel Löschinger Karen Hamann, Anna Baumann, Psychology of Environmental Protection Handbook for Encouraging Sustainable Actions (München: oekom verlag, Gesellschaft für ökologische Kommunikation mbH, 2016).

47 Gifford, Robert, Joseph P. Reser and, Linda Steg, Environmental Psychology, ed. Martin (Ed)., The IAAP Handbook of Applied Psychology, First Edition. Ltd., (Blackwell Publishing Ltd, 2011). 
title "Ending Ecological Injustice Development". ${ }^{48}$ In essence, in that reflection I submit that in the context of infrastructure development, the passion for development can be fruitful but can also have an impact on ecological injustice, depending on the disposition of the leader in responding to existing problems.

Based on my praxis and involvement in dealing with these three environmental problems, for the moment, I describe the nature and out-comes of the interreligious ecotheological leader characteristics as summary of recommendations as follows. There are at least six characteristics of interreligious ecotheological leaders. First, she/he empathized as homo sympathetikos ${ }^{49}$ (person who is filled with God's empathy) to listen to and fight alongside the victims of environmental issues. Second, she/he synergized with all parties happily for good (bonum) and beauty (pulchrum) in the interest of the universe through cultural artistic expression. Third, she/he lived in harmony by developing solidarity for and with the Earth and the Poor by living the preferential option for and with the Earth and the Poor. Fourth, she/he prophetically evaluated mistakes through dialogue in the face of environmental problems and ecological crisis. Fifth, she/he bravely and lovingly shouted for ecological repentance ${ }^{50}$ to themselves and others for the sake of the integrity of creation and environmental preservation. Last but not least, she/ he never gave up realizing faith, hope and love to care the Earth, our common home. Thus, the last is the basis of interreligious ecotheological leadership, regardless of her/his religion and beliefs. Here, I further develop the conceptualization of the characteristics of the interreligious ecotheological based on the paper I wrote earlier. ${ }^{51}$ In the previous paper, my research was based on one case in Tambakrejo only in the perspective of environmental science, while in this paper, I based on three environmental cases, namely Tambakrejo, Kendeng and Gedongsongo in the contextual theology perspective.

48 Aloys Budi Purnomo, “Mengakhiri Ketidakadilan Ekologis Pembangunan,” Kompas (Jakarta, 2019), https: / /kompas.id/baca/opini/2019/08/07/mengakhiri-ketidakadilan-ekologis-pembangunan (accessed 10.08.2019)

49 I learn this term of homo sympathetikos from Abraham Joshua Heschel, The Prophets (New York: Perennial Classics, 2001), p. 395.

50 Pope Francis, Laudato Si'. 216-221

51 See Aloys Budi Purnomo, “Constructing and Conducting an Interreligious Ecotheology...” p. 1497 
The fruit/result of the interreligious ecotheological leadership is the realization of a civilization of love for the Earth and a prosperous, dignified and faithful humanity, regardless of religion or belief. ${ }^{52}$

To the extent of my limited knowledge, these six characteristics have been proven and lived through my personal experience as a priest who is featured in an interreligious perspective. That is what happened in Tambakrejo. We are together with the activists joined in two domains, namely "\#RakyatBantuRakyat (\#PeopleHelpingPeople)" in the context of raising accommodations and facilitating material needs for residents and "Love Stage" as a joint movement of artists and interreligious community leaders.

The struggle with the fishermen in the Tambakrejo City of Semarang is included in the category of success in implementing of the characteristics of the interreligious ecotheological leadership. So, it can be a positive example of inspirational, fruitful patterns of the interreligious ecotheological leadership in dealing with environmental problems. The indicator phenomenon is that, after inhumane evictions, the parties involved can sit together for dialogue. The Mayor of Semarang City also listens to various parties' input. The fact of eviction also resulted in dialogue and the welfare of victims. An ecological justice in development is realized. The city government not only facilitates temporary shelters, but also designs permanent shelters for residents, including ensuring and inaugurating the post-eviction mosque and Al-Quran education park. The position of the victims is changed by welfare. Structuring the development of the local area is done by involving citizens in a humane way. The experience in Tambakrejo, by presenting the five ${ }^{53}$ characteristics of the interreligious ecotheological leadership, efforts to overcome environmental problems and ecological crises bear fruit in empowering and protecting local communities. Instead of leaving injustice, the interreligious ecotheological leaders can inherit prosperity, ecological justice, integrity of creation and environmental preservation for future generations.

52 Cf. DKP-KAS, Menuju Terwujudnya Peradaban Kasih Bagi Masyarakat Indonesia Yang Sejahtera, Bermartabat, Dan Beriman (Muntilan: DKP, 2015). See also Aloys Budi Purnomo, "Peradaban Kasih Persaudaraan," Kompas, (Jakarta, March 3, 2018).

53 Starting from the five characteristics of interreligious ecotheological leadership in Tambakrejo according to the perspective of environmental sciences, now, enriched with the case of North Kendeng Mountainsn Region and Gedongsongo in a contextual theological perspective, the characteristics of the interreligious ecotheological leader increased to six with an essential addition to faith, hope and love. This last characteristic is precisely the source of strength although the struggle seems to have not succeeded definitively. 
In particular, for the problems in KPKU (Kendeng Mountains) and KCBCG (Gedongsongo temple), all parties are still in a struggle that has not been fully successful. People and many activists are still in a continuing struggle that has not been successful. An extreme indicator of its success is that cement factory does not operate in North Kendeng Mountains and plan to construct geothermal power plants is discontinued in Gedongsongo. However, we are still grateful that caring for the Earth as our common home remains a concern for many. The struggle of the interreligious ecotheological leaders with local citizens and activists still continues. At least, thanks to God and to the interreligious ecotheological leaders carried out by many parties, that the cement factory in Rembang has not yet operated, the development plan in the new place has not yet been released, and reviews of related parties continue to be carried out. The same thing with the plan of establishing a geothermal power plant in Gedongsongo. To this day, we all still struggle tirelessly and relentlessly.

Yet, the struggle is not over because the ecological crisis would still continue. Therefore, based on my existing experience, the interreligious ecotheological leaders are most needed in the future. Especially in Indonesia as the biggest Muslim-population country in the world characterized by diversity and openness to cooperate in addressing the ecological crisis, the paradigm of interreligious ecotheological leadership to overcome the ecological crisis is really needed now and in the future.

Here is a diagrammatic figure summarizing all the ideas and praxis I reflect in this paper. The summary of recommendations related to the nature and outcomes of the interreligious ecotheological leader characteristics can be figured as follows. 


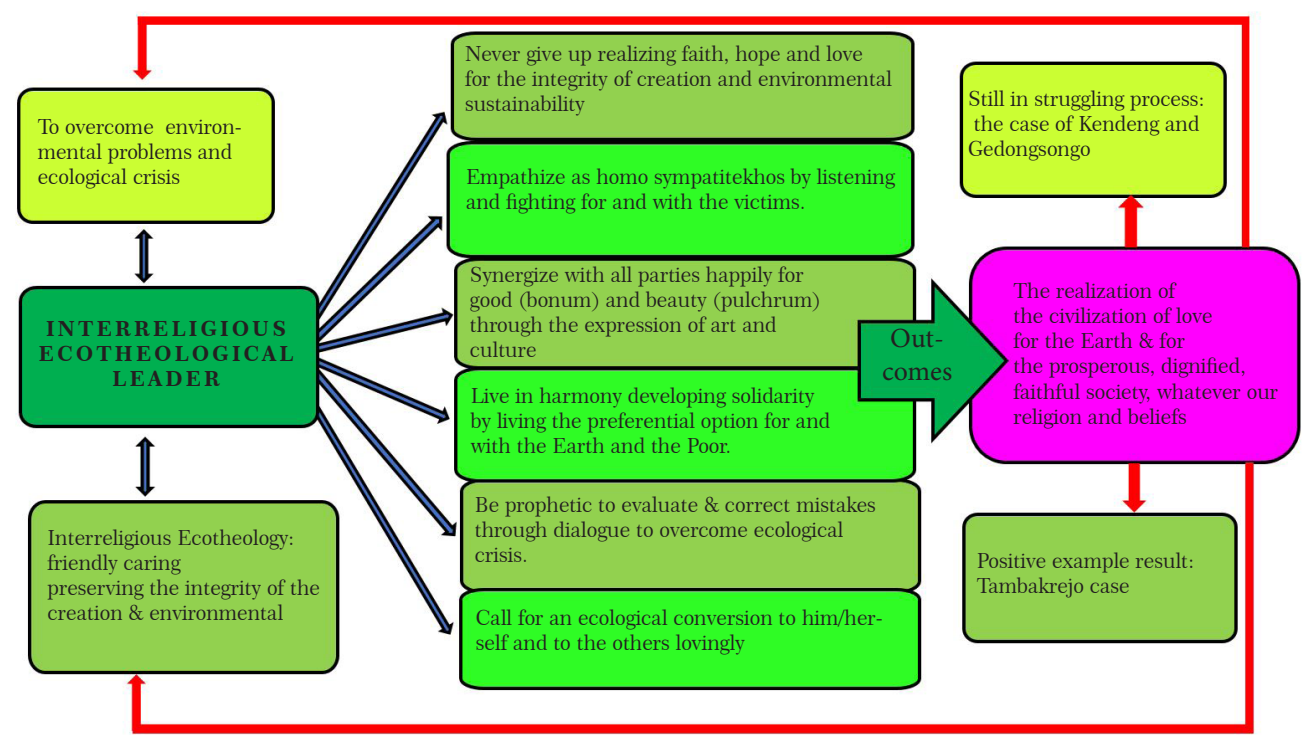

Figure 2: Summary of Recommendations: The Out-comes and of the Interreligious Ecotheological Leaders Characteristics

\section{An Open Conclusion for the Next Research}

Of course, the idea written in this essay is not a final point but rather a starting point of departure to a common movement to maintain the integrity of creation and environmental preservation, caring for the Earth as our common home. So, after the previous "recommendative" summary of the essay, allow me to conclude this paper with an open conclusion for the next research. This paper is in fact just a background to preparing an initial proposal research to construct a paradigm or model of the interreligious ecotheological leadership in order to overcome the ecological crisis that will still be researched further through a qualitative research based on the experience and personal praxis of mine with illuminated by the Catholic Social Teachings and the traditions of other religions and literature available for the benefit of this study.

The paradigm of the interreligious ecotheological leadership needs to be constructed alongside the various concepts of existing leadership to overcome the ecological crisis by evaluating the misperception, the wrong perspective and the error of human behaviour of the Earth and its contents. An increasingly greater consciousness would be the cause of the ecological crisis encouraging religions to immediately evaluate the mistakes of perception, perspective and human behaviour, especially leaders in response to environmental issues. Based on my interreligious 
experience (praxis) in order to safeguard the integrity of creation and environmental preservation, the role of the leader with the interreligious ecotheological paradigm has quite significant influence for us all and the next generations!

Given the experience and positive outcome of the struggle in Tambakrejo case as I wrote in my paper titled "Constructing and Conducting an Interreligious Ecotheological Leadership in Environmental Science Perspective" 54 ; while writing this paper, I think of another possibility to examine an interreligious ecotheological leadership model based on the encyclical Laudato Si'. So, in the future, I will focus more on the library research to further examine the interreligious ecotheological leadership based on the encyclical Laudato Si'. While concluding this essay, I was increasingly confident and steady to do the new research on the interreligious ecotheological leadership model based on the encyclical Laudato Si'. It would be a qualitative study in theory-developing method as a desk-research type as offered by Piet Verschuren and Hans Doorewaard. ${ }^{55}$ That means, I no longer need to plunge into the field. Even, this paper can also be a source of data for the desk-research type. I hope that this decision will be the best in caring for the Earth, our common home. Moreover, the call of Pope Francis will still remain relevant and significant in the future precisely due to the unending ecological crisis which afflicts the Earth, our common home.

54 Aloys Budi Purnomo, “Constructing and Conducting an Interreligious Ecotheology...” pp. 1497-1501.

55 Piet Verschuren dan Hans Doorewaard, Designing A Research Project (The Haag: Eleven International Publishing, 2010). 


\section{BiblogRAPHY}

Ardoin, Nicole M.; Rachelle K. Gould, Elin Kelsey \& Priya Fielding-Singh. "Collaborative and Transformational Leadership in the Environmental Realm." Journal of Environmental Policy E Planning, 17:3, 360-380 (2015).

Arh. "Warga, Seniman, Dan Pegiat Lingkungan Hidup Menolak Pembangunan PLTPB Gunung Ungaran.” Tribun Jateng. Ungaran, 2019.

Belser, Julia Watts. "Environmental Justice and Interreligious Ecotheology." Religious Studies News. Last modified 2013. Accessed September 30, 2019. http://rsn.aarweb.org/spotlight-on/theo-ed/environemental-justice/environmental-justice-and-interreligious-ecotheology.

Berry, Thomas. The Christian Future and the Fate of Earth. Edited by John Evelyn, Mary; Grim. Maryknoll, New York: Orbis Books, 2009.

Boff, Leonardo. Cry of the Earth, Cry of the Poor. New York: Orbis Books, 1997. Ecology and Liberation: A New Paradigm. New York: Orbis Books, 2000.

Brymer, Eric. "Ecological Leadership: A New Perspective on Leadership." Journal of Spirituality, Leadership and Management (SLaM), Spirituality, Leadership and Management Incorporated (NSW), St Josephs Centre for Reflective Living, Baulkham Hills, NSW, (2010): 84-94.

Capra, Fritjof. The Hidden Connections. London: Flamingo, 2003.

Capra, Fritjof., and V. N. Mansfield. The Tao of Physics: An Exploration of the Parallels Between Modern Physics Ad Eastern Mysticism. Physics Today. Vol. 29. Boston: Shambhala, Year: 2010, 1976.

Case, Peter, Louisa S. Evans, Michael Fabinyi, Philippa J. Cohen, Christina C. Hicks, Murray Prideaux, and David J. Mills. "Rethinking Environmental Leadership: The Social Construction of Leaders and Leadership in Discourses of Ecological Crisis, Development, and Conservation." Leadership 11, no. 4 (2015): 396-423.

Chen, Chin Yi, and Chin Fang Yang. "The Impact of Spiritual Leadership on Organizational Citizenship Behavior: A Multi-Sample Analysis." Journal of Business Ethics 105, no. 1 (2012): 107-114.

Cobb, John B. Is It Too Late? A Theology of Ecology. Denton, Texas: Environmental Ethics Books, 1995. 
comANDRE. "Inspirasi Perlawanan Dari Warga Samin Lawan Industri Semen." Kaskus.Co.Id. Last modified 2015. https://www.kaskus. co.id/thread/54f700db138b46fa278b4576/dokumenter-perjuangan-samin-melawan-industri-semen/.

Crossman, Joanna. "Conceptualising Spiritual Leadership in Secular Organizational Contexts and Its Relation to Transformational, Servant and Environmental Leadership." Leadership and Organization Development Journal 31, no. 7 (2010): 596-608. www.emeraldinsight.com/01437739.htm.

Dalton, Anne M; Simmons, Herry C. Ecotheology and the Practice of Hope. New York: Sunny Press, 2010.

DKP-KAS. Menuju Terwujudnya Peradaban Kasih Bagi Masyarakat Indonesia Yang Sejahtera, Bermartabat, Dan Beriman. Muntilan: DKP, 2015.

Dorr, Donal. Option for the Poor and the Earth: Catholic Social Teaching. New York: Orbis Books, 2012.

Dyk, Peet J. van. “'Responsible Stewardship' - The Root of All Evil in Eco-Theology?" OTE 28/2 (2015): 523-535 (2015). https://pdfs.semanticscholar.org/c344/90ecc21ae07a1b7c5c82fd2ca619c29e397a.pdf? $\mathrm{ga}=2.142747699 .726734814 .1569827902-968639214.1569827902$.

Francis, Pope. Laudato Si': On Care for Our Common Home. Vatican: Libreria Editrice Vaticana, 2015.

—. "Laudato Si': Encyclical on the Environment." Origins. Last modified 2015. Accessed June 17, 2019. https://focusoncampus.org/content/ summary-of-laudato-si-pope-francis-encyclical-on-the-environmentbfaf7861-99b2-413b-a736-9d883805ebc5.

Fry, Louis W. Spiritual Leadership - Global Encyclopedia of Public Administration, Public Policy, and Governance. Edited by Ali (Ed) Farazmand. Springer International Publishing Switzerland. Florida Atlantic University Boca Raton, FL, USA: Global Encyclopedia of Public Administration, Public Policy, and Governance, 2018. https://www.iispiritualleadership.com/ wp-content/uploads/Spiritual-Leadership-Public-Administration_Final.pdf.

Gifford, Robert; Linda Steg, and Joseph P. Reser. Environmental Psychology. Edited by Martin (Ed). The IAAP Handbook of Applied Psychology, First Edition. Ltd.,. Blackwell Publishing Ltd, 2011.

Goh, Jeffrey. "The Place of the Poor in Laudato Si'." Asian Horizons: Dharmaram Journal of Theology 9, no. 4 (2015): 645-657. http://w2.vatican.va/content/francesco/en/encyclicals/documents/papa-frances- 
co_20150524_enciclica-laudato-si.html.

Groot, Linda Steg and Judith I M de. Environmental Psychology : An Introduction. Edited by Judith I. M. Steg, Linda. Second edi. New Jersey: John Willey \& Sons, Inc, 2019.

Hadiwardoyo, Al. Purwa. Teologi Ramah Lingkungan, Sekilas Tentang Ekoteologi Kristiani. Yogyakarta: Kanisius, 2015.

Hamann, Karen; Anna Baumann, Daniel Löschinger. Psychology of Environmental Protection Handbook for Encouraging Sustainable Actions. München: oekom verlag, Gesellschaft für ökologische Kommunikation $\mathrm{mbH}, 2016$.

Heschel, Abraham Joshua. The Prophets. New York: Perennial Classics, 2001.

Keraf, A. Sony. Krisis Dan Bencana: Lingkungan Hidup Global. Yogyakarta: Kanisius, 2010.

Keraf, A. Sony. Filsafat Lingkungan Hidup Alam Sebagai Sebuah Sistem Kehidupan. Yogyakarta: Kanisius, 2014.

Kunjana, LGora. "Menjaga-Bumi-Pertiwi-Warga-Kendeng-Longmarch-Ke-Semarang@Www.Beritasatu.Com.” Jakarta: beritasatu.com, 2016. https:// www.beritasatu.com/nasional/403670/menjaga-bumi-pertiwi-warga-kendeng-longmarch-ke-semarang.

Lako, Andreas, and Dkk, Pogram Doktor Ilmu Lingkungan. Arah Dan Filosofi Konsentrasi Kepemimpinan Lingkungan. Semarang, 2019.

Lewin, Kurt. Princuoles of Topological Psychology. New York and London: McGraw-Hill Book Company, Inc, 1936.

Lonergan, Bernard. Method in Theology. New York: Herder \& Herder, 1972.

McDonagh, Sean, ed. On Care for Our Common Home. Laudato Si': The Encyclical Commentary. Maryknoll: Orbis Books, 2016.

Purnama, Finsensius Yuli. Semen vs Samin: The Impact of "Change.Ord" Online Petition in Perspective of Laudato Si'. Reading Laudato Si' in Asia and the Pacific. Vol. LII. Special Issue. Manila, 2017.

Purnomo, Aloys Budi. "Constructing and Conducting an Interreligious Ecotheological Leadership in Environmental Science Perspective." International Journal of Engineering and Advanced Technology (IJEAT) Volume-9, no. Issue-2 (2019).

"Memperjuangkan Kemerdekaan Semesta." Tribun Jateng. Semarang, 2019. https://jateng.tribunnews.com/2019/08/21/opini-aloys-budi-purnomo-memperjuangkan-kemerdekaan-semesta. 
"Mengakhiri Ketidakadilan Ekologis Pembangunan." Kompas. Jakarta, 2019. https://kompas.id/baca/opini/2019/08/07/mengakhiri-ketidakadilan-ekologis-pembangunan.

__. "Peradaban Kasih Persaudaraan.” Kompas. Jakarta, March 3, 2018.

"Praksis Merawat Bumi." Suara Merdeka. Semarang, August 2019. https://www.suaramerdeka.com/smcetak/baca/192145/praksis-merawat-bumi.

. Preferential Option for and with the Poor. Medan: Bina Media, 2003.

_ . "Reportase Long March Menjemput Keadilan Demi Keutuhan Ciptaan." Sesawi.Net. Last modified 2015. http://www.sesawi.net/reportase-longmarch-menjemput-keadilan-demi-keutuhan-ciptaan/.

Spiritualitas Pembebasan. Yogyakarta: Yayasan Pustaka Nusatama, 2002.

Rachman, Bowo Pribadi dan Taufik. "Warga Gedongsongo Tolak PLTTB." Republika.Co.Id. Last modified 2010. https://www.republika.co.id/berita/ breaking-news/nusantara/10/08/09/128905-warga-gedongsongo-tolak-plttb.

Robertson, Jennifer L. and, and and Erica Carleton. "Uncovering How and When Environmental Leadership Affects Employees' Voluntary Pro-Environmental Behavior." Journal of Leadership \& Organizational Studies 1-14 14 (2017). https://doi.org/10.1177/1548051817738940\%0AArticle information \%0A.

Schuck, Michael J. “Pope Francis Laudato Si'.” Concilium Vatican. Last modified 2015. Accessed June 17, 2019. http://w2.vatican.va/content/francesco/ en/encyclicals/documents/papa-francesco_20150524_enciclica-laudato-si.html.

Spencer, Andrew J. "Beyond Christian Environmentalism: Ecotheology as an Over-Contextualized Theology." Themelios 40.3 (2015): 414-28 (2015).

Verschuren, Piet dan Hans Doorewaard. Designing A Research Project. The Haag: Eleven International Publishing, 2010.

Wahid, KH Abdurrahman, and Daisaku Ikeda. "Dialog Peradaban Untuk Toleransi Dan Perdamaian.” Jakarta: PT Gramedia Pustaka Utama, 2013.

Waterman, A. M.C. "Pope Francis on the Environmental Crisis." Independent Review, 2017. https://www.independent.org/publications/tir/article.as$\mathrm{p}$ ?id $=1182$. 
Western, Simon. "Eco-Leadership: Towards a New Paradigm" (2007). https:// www.academia.edu/605304/Eco-Leadership_Towards_a_new_paradigm.

Widianarko, Y Budi. Environmental Leadership. Semarang, 2019.

Wilfred, Felix. "Toward Inter-Religious Eco-Theology." Edited by Luiz Carlos Susin and Felix Wilfred Elaine Wainwright. Concilium 2009/3 (2009): 43-54. https://archive.org/details/ecotheology0000unse/page/n6. 
